\title{
The Dominance of Established Equivalent in the Metaphor Translation
}

\author{
Dwi Aji Prajoko ${ }^{1}$ \\ \{dwiaji.prajoko@gmail.com 1 \} \\ Universitas Katolik Widya Mandala Surabaya $^{1}$
}

\begin{abstract}
This study aimed to describe the techniques used in the translation of the conceptual metaphor expressions. The data were linguistic units in the form of words, phrases, or clauses about the American dream expressed in conceptual metaphor. The sources of the data were the original novel entitled The Great Gatsby and its Indonesian versions translated successively by Nataresmi (2010) and Verawaty (2010). Data collection was carried out by document analysis and focus group discussions (FGD). The result of the study showed that the most dominant techniques were established equivalent. The dominance is caused by the availability of similar metaphorical expressions in the target language as the equivalent and the stock of similar metaphorical concepts in the target language that make the translators create new expressions. Modulation in the third position is also interesting since metaphors with different expressions and concepts are possible to be translated.
\end{abstract}

Keywords: translation, conceptual metaphor, technique, established equivalent

\section{Introduction}

A translation technique called established equivalent can be used only if a term or expression used in the source language (SL) is recognized by dictionaries or language in use as an equivalent in the target language (TL) [1]. Recognized by dictionaries and language in use implies that both languages have similar expressions. Since it is about metaphor translation, the similarities are against some experts saying that Thai and Japanese are close in term of using metaphorical concept; those two Asian countries share a monistic character; they do not rigidly separate between head and heart. Emotive and rational aspects are integrated in their interpersonal relationship reflected in their metaphor. On the contrary, English is dualistic so there is a sharp dichotomy between emotions (heart) and rationality (head/mind) [2]. If Indonesian is similar to the other two Asian languages, metaphor translation from English into Indonesian does not enjoy any facilitation. This is strengthened by the standpoint that readers will be difficult to understand metaphorical expressions based on different conceptual metaphors (Lakoff \& Johnson, 2003) [3].

Mccune (1985) [4], however, empirically proves that English and Indonesian have similarities; he finds nine similar metaphorical concepts, namely CORRECTNES IS STRAIGHTNESS, THOUGHTS ARE MOTIONS, TIME IS SPACE, CHANGE IS MOTION, HEARING IS TOUCHING, UNPLEASANTNESS IS SHARPNESS, INTERELATING IS TOUCHING, SOUND IS A SUBSTANCE, CONCIOUSNESS IS A FLUID. He investigates that the similarities are caused by human cognition and borrowing. All humans are very likely to have a common understanding for certain things because of their belonging to the same race: human beings. The notion of borrowing is analogous to the case of English which also borrows a lot of metaphors from Hebrew culture through the Bible.

The dominance of establised equivalent may make moniistic-dualistic approach causing the differences insignificant. Nevertheless, the dominance may refer to something more than 
strengthening the human cognition and borrowing thesis. Hopefully, this research finds some new perspectives on metaphor translation and triggers the other researchers to find more.

\section{Methodology}

\subsection{The design of the study}

This research is qualitative; accordingly, it is descriptive because the data are mostly in the form of words. Numbers used are not the formulas of quantitative research. Furthermore, this qualitative research includes content analysis, case studies, and comparative studies, which are actually research methods. This confirms that, "Qualitative research is an umbrella term under which a variety of research methods that use languaged data are clustered" (Polkinghorne, 2005) [5].

\subsection{Subjects of the research}

Subjects of the researh are a data validater, raters, and the researcher. A data validater is an expert who decides whether the data about American dream expressed in metaphors gathered by the researcher are valid. Raters are translation experts who determine translation techniques; the raters are a translation proffesor and three senior doctorate students majoring in translation including the researcher.

\subsection{Data collection procedures}

The data were American dream metaphorical expressions found in the novel The Great Gatsby (TGG) witten by Fitzgerald [6] and in its two Indonesian versions in which one was translated by Nataresmi (TGG-N) [7] and the other by Verawaty (TGG-V) [8]. The data about American dream metaphorical expressions and their translations were collected by analizing documents, namely the original novel and the two translations. The data were also about the translations techniques used by the two translators. These ones were obtained through focus group discussions (FGD).

\subsection{Data analysis techniques}

The research data analysis techniques were domain analysis, taxonomic analysis, componential analysis, and cultural theme analysis (Spradley, 2007) [9]. The domain analysis was used to include the data about the American dream metaphorical expressions and to exclude the others. The taxonomic analysis was to analyze all of the data based on predefined domains, namely the translation techniques. The componential analysis was to compare between the translation techniques of TGG-N and that of TGG-V. The cultural theme analysis was to conclude the relationship patterns between the domains and how they were linked to the culture as a whole. 


\section{Findings and Discussion}

\subsection{Translation techniques of metaphor in TGG}

Molina \& Albir (2002) have 18 techniques of translation [1]. Nevertheless, this research integrates word to word translation to literal; but explicitation, addition, paraphrase, and footnote are counted individually. Similarly, pure borrowing and naturalized borrowing are counted two and so are implicitation and deletion. Accordingly, they are 22 techniques alltogether. The ones used in TGG-N and TGG-V are thirdteen, namely adaptation, addition, deletion, discursive creation, explicitation, established equivalent, generalisation, literal, modulation, particularisation, pure borrowing, reduction, transposition. It can be seen in the Table 1

Table 1

Translation technique of American dream metaphor

\begin{tabular}{|c|c|c|c|c|}
\hline No & Translation technique & $\begin{array}{l}\text { TGG-N } \\
\text { (Sum / Percentage) }\end{array}$ & $\begin{array}{l}\text { TGG-V } \\
\text { (Sum / Percentage) }\end{array}$ & $\begin{array}{l}\text { Percentage } \\
\text { average }\end{array}$ \\
\hline 1. & Established equivalent & $100 / 41,67$ & $147 / 61,25$ & 51,46 \\
\hline 2. & Explicitation & $38 / 15,83$ & $45 / 18,75$ & 17,29 \\
\hline 3. & Modulation & $40 / 16,67$ & $13 / 5,42$ & 11,04 \\
\hline 4. & Discursive creation & $36 / 15,00$ & $13 / 5,42$ & 10,20 \\
\hline 5. & Deletion & $9 / 3,75$ & $4 / 1,67$ & 2,70 \\
\hline 6. & Transposition & $4 / 1,67$ & $3 / 1,25$ & 1,46 \\
\hline 7. & Literal & $1 / 0,42$ & $4 / 1,67$ & 1,04 \\
\hline 8. & $\begin{array}{l}\text { Established equivalent + } \\
\text { Reduction }\end{array}$ & $2 / 0,83$ & $2 / 0,83$ & 0,83 \\
\hline 9. & Generalisation & $2 / 0,83$ & $1 / 0,42$ & 0,64 \\
\hline 10. & Pure borrowing & $1 / 0,42$ & $1 / 0,42$ & 0,42 \\
\hline 11. & $\begin{array}{l}\text { Established equivalent + Pure } \\
\text { borrowing }\end{array}$ & $1 / 0,42$ & $1 / 0,42$ & 0,42 \\
\hline 12. & $\begin{array}{l}\text { Established equivalent }+ \\
\text { Discursive creation }\end{array}$ & $1 / 0,42$ & $1 / 0,42$ & 0,42 \\
\hline 13. & Particularisation & $1 / 0,42$ & $0 / 0$ & 0,21 \\
\hline 14. & $\begin{array}{l}\text { Established equivalent + } \\
\text { Explicitation }\end{array}$ & $1 / 0,42$ & $0 / 0$ & 0,21 \\
\hline 15. & $\begin{array}{l}\text { Explicitation + Discursive } \\
\text { creation }\end{array}$ & $1 / 0,42$ & $0 / 0$ & 0,21 \\
\hline 16. & Modulation + Pure borrowing & $1 / 0,42$ & $0 / 0$ & 0,21 \\
\hline 17. & $\begin{array}{l}\text { Established equivalent + } \\
\text { Addition }\end{array}$ & $1 / 0,42$ & $0 / 0$ & 0,21 \\
\hline 18. & Adaptation & $0 / 0$ & $1 / 0,42$ & 0,21 \\
\hline 19. & $\begin{array}{l}\text { Established equivalent + } \\
\text { Adaptation }\end{array}$ & $0 / 0$ & $1 / 0,42$ & 0,21 \\
\hline 20. & $\begin{array}{l}\text { Transposition + Pure } \\
\text { borrowing }\end{array}$ & $0 / 0$ & $1 / 0,42$ & 0,21 \\
\hline \multirow[t]{2}{*}{21.} & Literal + Deletion & $0 / 0$ & $1 / 0,42$ & 0,21 \\
\hline & Total & $240 / 100$ & $240 / 100$ & 100 \\
\hline
\end{tabular}

American dream expressed in metaphor are the criteria of data inclusion. American dream cannot be separated from happiness (the goal), wealth (the means to reach the goal), and conducive situation: optimism, opportumity, and hardworking [10]. Metaphorical expressions are linguistic manivestation of the metaphorical concept; metaphor itself is just about saying 
one thing in terms of another [3]. Some data in the following are elaborated based on the notions while their techniques are categorized with Molina and Albir's ideas [1].

\subsubsection{Established equivalent}

Established equivalent is a translation technique using terms or expressions or commonly known as equivalents in the TL. They are recognized by dictionaries or language in use [1].

Table 2. Translating with established equivalent

\begin{tabular}{|c|c|c|c|}
\hline Source language & $\begin{array}{l}\text { Metaphorical concept / } \\
\text { American dream domain }\end{array}$ & Target language & $\begin{array}{l}\text { Translation } \\
\text { technique }\end{array}$ \\
\hline $\begin{array}{l}\text { 104/TGG/64 But I am } \\
\text { slow-thinking and full of } \\
\text { interior rules that act as } \\
\text { brakes on my desires }\end{array}$ & $\begin{array}{l}\text { DESIRES ARE A } \\
\text { SPEEDING CAR / } \\
\text { Conducive situation }\end{array}$ & $\begin{array}{l}\text { 104/TGG/64 But I am slow- } \\
\text { thinking and full of interior } \\
\text { rules that act as brakes on } \\
\text { my desires }\end{array}$ & $\begin{array}{l}\text { Established } \\
\text { equivalent }\end{array}$ \\
\hline
\end{tabular}

Nick is often referred to as the personification of an unspoiled American dream; this is because, among other things, his adherence to various regulations for him serves as a brake on certain desires that can disrupt the focus or pollute the process of achieving his American dreams. Accordingly, this attitude belongs to the conducive situation of the American dream. The word brakes in "brakes on my desires" is the datum because it is a metaphor based on the metaphorical concept DESIRES ARE A SPEEDING CAR.

Established equivalent is the technique used in translating the word brakes into rem due to two reasons. Firstly, the word rem is the equivalent of brake in English-Indonesian dictionary (Echols \& Shadily, 2010) [11]. Secondly, the metaphorical expression rem based on DESIRES ARE A SPEEDING CAR is widely used in Indonesian such as "rem atas hasrat/keinginan/ambisi/hawa nafsu" (brake on desire/want/ambition/lust) et cetera.

\subsubsection{Explicitation}

Explicitation is a translation technique that converts implicit information in the SL into detailed or explicit information in the TL [1].

Table 3. Translating with explicitation

\begin{tabular}{llll}
\hline Source language & $\begin{array}{l}\text { Metaphorical concept / } \\
\text { American dream } \\
\text { domain }\end{array}$ & Target language & $\begin{array}{l}\text { Translation } \\
\text { technique }\end{array}$ \\
\hline 023/TGG/8 ... but now & WONDER IS A & 023/TGG-V/15 ... dan sekarang & Explicitation \\
he'd left Chicago and & BREATH TAKER/ & $\begin{array}{l}\text { dia telah meninggalkan Chicago } \\
\text { dan datang ke East dengan gaya }\end{array}$ & \\
$\begin{array}{l}\text { come east in a fashion } \\
\text { that rather took your }\end{array}$ & Wealth & $\begin{array}{l}\text { yang akan membuatmu } \\
\text { tercengang. }\end{array}$ & \\
breath away & & termation & \\
\hline
\end{tabular}

Tom Buchanan's wealth, exemplified by his carrying along with many expensive ponies when moving from Lake Forest to East, surprises many people; this astonishment is expressed metaphorically with took your breath away based on the metaphorical concept WONDER IS A BREATH TAKER. Therefore, the phrase took your breath away becomes the datum.

Explicitation causes the metaphorical expression took your breath away to be translated into membuatmu tercengang (make you get amazed). The reason is that the TL phrase whose meaning is implied by metaphorical expression becomes the SL phrase whose meaning is explicit. The SL metaphor, whose meaning is implicit, is not retained. The same thing happens 
when enormously in "His family were enormously wealthy" (022 / TGG / 8) is translated as sangat (very) in "Keluarganya sangat kaya" (022/TGG-N/7).

\subsubsection{Modulation}

Modulation is a translation technique that changes the point of view, focus, or cognitive categories [1].

\begin{tabular}{|c|c|c|c|}
\hline Source language & $\begin{array}{l}\text { Metaphorical concept / } \\
\text { American dream } \\
\text { domain }\end{array}$ & Target language & $\begin{array}{l}\text { Translation } \\
\text { technique }\end{array}$ \\
\hline $\begin{array}{l}018 / \text { TGG/7 To the } \\
\text { wingless a more } \\
\text { arresting phenomenon } \\
\text { is their dissimilarity in } \\
\text { every particular except } \\
\text { shape and size. }\end{array}$ & $\begin{array}{l}\text { A PHENOMENON } \\
\text { IS A HOLDER / } \\
\text { Happiness }\end{array}$ & $\begin{array}{l}\text { 018/TGG-N/6-7 Sedangkan } \\
\text { bagi makhluk tanpa sayap, } \\
\text { manusia, fenomena paling } \\
\text { menarik adalah ketidaksamaan } \\
\text { dalam setiap hal, kecuali bentuk } \\
\text { dan ukuran. }\end{array}$ & Modulation \\
\hline
\end{tabular}

Living in the same neighborhood as Gatsby in West Egg, Nick Carraway admires the beauty of the natural surroundings such as the birds loving to fly above him; the positive emotion is included in the most important domain of American dreams: happiness. Nick consideres the natural beauty that makes him happy as an arresting phenomenon based on the metaphorical concept A PHENOMENON IS A HOLDER. Therefore, the word arresting is the datum.

There is a debate among the raters regarding the translation technique used. First, the two raters classify it as established equivalent; the reason is that in this context menarik is seen in the dictionary and in the language use as the equivalent of arresting. Secondly, the other two raters identify it as modulation because there is a change in perspective. The word arresting meaning catching has a cognitive category which is different from its translation, namely menarik (pulling) although both have the same metaphorical concept. Because both arguments are strong while the decision must be made, it is stated that the technique is modulation merely because the writer is on the side of such an opinion.

\subsubsection{Discursive creation}

Discursive creation is a translation technique that establishes a temporary equivalence that is totally unpredictable out of context [1].

Table 5. Translating with discursive creation

\begin{tabular}{|c|c|c|c|}
\hline Source language & $\begin{array}{l}\text { Metaphorical concept / } \\
\text { American dream } \\
\text { domain }\end{array}$ & Target language & $\begin{array}{l}\text { Translation } \\
\text { technique }\end{array}$ \\
\hline $\begin{array}{l}\text { 044/TGG/16 He reads } \\
\text { deep books with long } \\
\text { words in them. }\end{array}$ & $\begin{array}{l}\text { BOOKS ARE } \\
\text { DEPTH / Conducive } \\
\text { situation }\end{array}$ & $\begin{array}{l}\text { 044/TGG-N/18-9 Ia membaca } \\
\text { dengan tekun buku-buku yang } \\
\text { berisi tulisan panjang." }\end{array}$ & $\begin{array}{l}\text { Discursive } \\
\text { creation }\end{array}$ \\
\hline
\end{tabular}

Quality books that have a high level of difficulty metaphorically in English are often referred to as deep books. It is based on the metaphorical concept BOOKS ARE DEPTH. Nick expresses his appreciation to Gatsby who has a positive view on books by studying such books. Gatsby's attitude belongs to the domain of the conducive situation in achieving the American dream. Therefore, deep becomes the datum. 
When Kucumbui Tubuh Indahku (I fondle my beautiful body), a drama film directed by Garin Nugroho, is translated into Memories of My Body (Kenangan Tubuhku), the translation can be justified in certain contexts, namely for eye catching so as to attract people to watch the movie. This creative creation is called discursive creation. Similarly, the phrase dengan tekun (diligently) in the discourse is also clear and natural. However, it is against the translation techniques working for the equivalent. This is, therefore, classified as discursive creation. The word deep in deep book which means quality and difficult explaining the book, while the word diligently modifies reading. Besides, it is not the equivalent of deep.

\subsubsection{Deletion}

Deletion is a translation technique that eliminates the SL words in the TL; the words are deleted, not reduced, not implied, or others [1].

Table 6. Translating with deletion

\begin{tabular}{|c|c|c|c|}
\hline Source language & $\begin{array}{l}\text { Metaphorical concept / } \\
\text { American dream } \\
\text { domain }\end{array}$ & Target language & $\begin{array}{l}\text { Translation } \\
\text { technique }\end{array}$ \\
\hline $\begin{array}{l}\text { 020/TGG/8 Across the } \\
\text { courtesy bay the white } \\
\text { palaces of fashionable } \\
\text { East Egg glittered } \\
\text { along the water. }\end{array}$ & $\begin{array}{l}\text { MODERN IS } \\
\text { FASHIONABLE / } \\
\text { Wealth }\end{array}$ & $\begin{array}{l}\text { 020/TGG-N/7 Di seberang teluk } \\
\text { kecil, bangunan-bangunan } \\
\text { berwarna putih berjejer di tepian } \\
\text { air sepanjang East Egg yang } \\
\text { gemerlapan. }\end{array}$ & Deletion \\
\hline
\end{tabular}

Portraits of America in the 1920s are recorded by Fitzgerald in the novel The Great Gatsby published in 1926. In those days, the term flappers appears to refer to the style of American women in that era. They have changed a lot. It can be traced in various mass media that their thoughts and attitudes are more open and prominent. Their makeup, hair styles, and manners of dress also look more fashionable. Not surprisingly, the phrase fashionable is adopted to represent that era. The phrase fasionable East Egg refers to various buildings in the region inhabited by very wealthy persons. This becomes the datum since it is an American dream domain and a linguistic manifestation of the metaphorical concept MODERN IS FASHIONABLE.

The word fashionable characterizes East Egg like a person who always follows the era progress so that they are beautiful. However, the metaphor is omitted in the translation. Deletion translation technique is used. Deletion also occurs when flower-like way (058/TGG/23) explaining Daisy is also lost in translation. The translated text loses information about Daisy's manner who is beautiful like a flower.

\subsubsection{Transposition}

Transposition is a translation technique that changes the SL grammatical categories into the TL ones [1].

Table 7. Translating with transposition

\begin{tabular}{llll}
\hline Source language & $\begin{array}{l}\text { Metaphorical concept / } \\
\text { American dream domain }\end{array}$ & Target language & $\begin{array}{l}\text { Translation } \\
\text { technique }\end{array}$ \\
\hline 007/TGG/4 ... some & LIFE IS A & 007/TGG-N/3 ... sesuatu yang & Transposition \\
heightened sensitivity & GENEROUS PERSON & $\begin{array}{l}\text { menunjukkan kepekaan tinggi } \\
\text { to the promises of life }\end{array}$ & \\
/.. Conducive situation & & $\begin{array}{l}\text { pada kehidupan yang } \\
\text { menjanjikan ... }\end{array}$ & \\
\hline
\end{tabular}


Gatsby has a high sensitivity to the promises of life; this shows the optimistic attitude which is included in the domain of the American dream. Therefore, the word promises in "promises of life" is data because it is also a linguistic metaphor based on the metaphorical concept LIFE IS A GENEROUS PERSON.

According to the word class, promises is a noun while promising is an adjective so that the word class has changed. The translation technique that changes grammatical category is transposition. This also happens when the noun burst in "vacuous bursts of laughter" (090/ TGG / 51) is translated into the adjective pecah (broken) in "gelak tawa terus pecah" (090/TGGN/64).

\subsubsection{Literal}

Literal is a translation technique that includes the word-for-word translation technique ignoring TL structures to the literal translation that obeying the TL structures; however, this technique produces a context-out translation [1].

Table 8. Translating with literal

\begin{tabular}{llll}
\hline Source language & $\begin{array}{l}\text { Metaphorical concept / } \\
\text { American dream domain }\end{array}$ & Target language & $\begin{array}{l}\text { Translation } \\
\text { technique }\end{array}$ \\
\hline 105/TGG/65 Every & PERSONS ARE & 105/TGG-V/95 Setiap orang & Literal \\
one suspects himself & GOODNESS / & mengira-ngira dirinya memiliki & \\
$\begin{array}{l}\text { of at least one of the } \\
\text { cardinal virtues, and }\end{array}$ & Conducive situation & $\begin{array}{l}\text { sesuatu atau setidaknya salah } \\
\text { this is mine }\end{array}$ & $\begin{array}{l}\text { satu kardinal kebajikan, dan } \\
\text { inilah kebajikanku }\end{array}$ \\
\hline
\end{tabular}

Nick believes he is taking part in making a better world; he claims to do at least one of the main virtues. This positive attitude towards oneself is encompassed by the domain of the conducive situation of the American dream. Next, the phrase the cardinal virtues becomes the datum because the metaphorical expression is based on the metaphorical concept PERSONS ARE GOODNESS.

The cardinal is the main official in the Roman Catholic Church who is hierarchically positioned only under the Pope. Therefore, cardinal virtues should be translated into kebajikan kardinal if you want to retain the metaphor or kebijakan utama if you want to make it explicit. The phrase kardinal kebajikan is literal since it is word-to-word translation that is out of context. It can be seen that the SL and TL phrases use the same structure, namely modifier (cardinal/kardinal) followed by modified (virtue/kebajikan) in which they do not adjust Indonesian structure.

\subsection{Metaphor translation technique similarities}

TGG-N and TGG-V have some similarities. Firstly, both versions manipulate target language-oriented techniques TGG-N gets 98,32 \% and TGG-V 96,65\%. The TL oriented techniques used by TGG-N are established equivalent, explicitation, modulation, discursive creation, deletion, transposition, established equivalent + reduction, generalisation, established equivalent + discursive creation, particularisation, established equivalent + explicitation, explicitation + discursive creation, established equivalent + addition. The SL oriented techniques are only literal, pure borrowing, established equivalent + pure borrowing, modulation + pure borrowing. The TL oriented techniques used by TGG-V are established equivalent, explicitation, modulation, discursive creation, deletion, transposition, established equivalent + reduction, generalisation, established equivalent + discursive creation, adaptation, 
established equivalent + adaptation. The SL oriented techniques used by TGG-V are only literal, pure borrowing, established equivalent + pure borrowing, transposition + pure borrowing, literal + deletion. Deletetion is used after considering that the expression is not important in the TL. Similarly, discursive creation is to attract the TL readers. Thus, both are TL techniques. Some data translated by the combination of TL and SL oriented techniques are grouped into SL oriented techniques. Secondly, the target language-oriented techniques are dominated by established equivalent; TGG-N 41,67 \% and TGG-V 61,9\%. Thirdly, the gaps between established equivalent and the other techniques are very large. The difference between established equivalent and the second rank technique is $25,83 \%$ in the TGG-N and $42,5 \%$ in the TGG-V.

\subsection{Reasons for the dominance}

Estabished equivalent techniques are dominant for two reasons. For one thing, metaphorical expression similarities can cause the data to be translated with established equivalent techniques since the expressions are found in dictionaries or in language use. For example, advantage in "all the people in this world haven't had the advantages that you've had" (001/TGG/3) is translated into keberuntungan in "tidak semua orang di dunia ini memiliki keberuntungan sepertimu." Another, metaphorical concept similarities can also cause the translators to create new expressions as the equivalent because they sound familiar eventhough they are not found on any dictionaries and language use. For example, full of money in "Her voice is full of money" (190/TGG/128) is translated into dipenuhi harta in "Suaranya dipenuhi harta" (190/TGGN/171). Both expressions are based on the same metaphorical concept GOOD QUALITY IS WEALTH which also breeds very familiar Indonesian phrase, namely "suara emas."

Besides the dominance of establised equivalent, modulation techniques in the third rank show Indonesian language flexibility. English and Indonesian metaphors can be totally different. However, the translation is still possible. For example, the metaphorical expression had in "I had that familiar conviction" (012/TGG/6) based on the metaphorical concept CONFIDENCE IS POSSESION is translated with the different expression merasakan in "aku merasakan sebuah keyakinan yang telah akrab" (012/TGG-N/5) based on the different metaphorical concept CONFIDENCE IS SENSUALITY.

\subsection{Implications of the dominance}

Three new perpectives can be generated from this research. Firstly, gone is the foreshadowing that translating English metaphor into Indonesian would find a lot of difficulties. Berendt \& Tanita (2011) [2] have highlighted the valuable differences between Eropean and Asian metaphors. This research, however, finds a lot of similarities not only between English and Indonesian metaphorical concepts but also between those two language metaphorical expressions. This also means that nine English and Indonesian similarities in terms of metaphorical concepts found by McCune (1985) [4] is an iceberg phenomenon. Secondly, the definition of established equivalent must be wider. It should not only cover the finding of words in dictionaries or in language use as the equivalent (Molina \& Albir 2002) [1] but also include the establishment of metaphorical concepts that their linguistic manivestations called metaphorical expressions have not found in dictionaries or language use. Thirdly, the notion that any conceptual metaphor cannot be understood by readers having different conceptual metaphor (Lakoff \& Johnson, 2003) [3] can be broken by translation. Modulation technique can be a bridge for that gap. 


\section{Conclusion}

The most commonly used translation techniques for the American dream metaphor of The Great Gatsby translated by Nataresmi and The Great Gatsby translated by Verawaty are the established equivalent, followed by the other three techniques with considerably wide gap, namely modulation, exploitation, and discursive creation. The dominance of the established equivalent technique in the translation of the American dream metaphor is influenced by two things. For one thing, metaphorical expressions in the source language are found in dictionaries or language in use in the target language. Another, authentic metaphorical expressions in the source language are not found in dictionaries or language in use in the target language, but new metaphorical expressions are created on the basis of the similar metaphorical concepts. Besides, modulation techniques in the third rank show the possibility of translating expressions eventhough the source and target languages have different metaphorical concepts.

This research, therefore, raises three new perspectives. Firstly, the foreshadowing of the difficulties in translating English metaphor into Indonesian is gone; a lot of similarities between English and Indonesian metaphors facilitate their translation. Secondly, the definition of established equivalent in metaphor translation may include the similar metaphorical concepts that very possibly produce familiar equivalent. Thirdly, the notion that any expressions cannot be understood by readers because of having different conceptual metaphors can be broken by translation especially by using a modulation technique.

\section{References}

[1] L. Molina and A. H. Albir, "Translation technique revisited: A dynamic and funcsionalist approach," Meta: Translators' Journal, vol. 47, no. 4, pp. 498-512, 2002.

[2] E. A. Berendt and K. Tanita, "The 'heart' of things: A conceptual metaphoric analysis of heart and related body parts in Thai, Japanese and English," Intercultural Communication Studies, vol. 20, no. 1, pp. 65-78, 2011.

[3]. G. Lakoff and M. Johnson, Metaphors We Live by. London, England: The University of Chicago Press, 2003.

[4] K. M. McCune, "The internal structure of Indonesian roots," part 1. Nusa, Linguistic Studies of Indonesian and Other Languages in Indonesia, vol. 21/22, pp. 87-121, 1985.

[5] D. E. Polkinghorne, "Language and meaning: Data collection in qualitative research," Journal of Counseling Psychology, vol. 52, no. 2, pp. 137-145, 2005.

[6] F. S. Fitzgerald, The Great Gatsby. (1925). Accessed [Online]: Apr. 13, 2014. Available: http://ebooks.adelaide.edu.au/

[7] F. S. Fitzgerald, The Great Gatsby, trans.: Sri Nur Verawati, Jakarta, Indonesia: Serambi (in Indonesian), 2010.

[8] F. S. Fitzgerald, The Great Gatsby, trans.: Ulya Nataresmi, Surabaya, Indonesia: Selazar (in Indonesian), 2010.

[9] J. P. Spradley, The Etnographic Interview, 2nd ed., trans.: Misbah Zulfa Elizabeth. Yogyakarta, Indonesia: Tiara Wacana, (in Indonesian) 2007.

[10] H. B. Johnson, The American Dream and the Power of Wealth. New York: Routledge, 2006.

[11] J. M. Echols and H. Shadily, Kamus Inggris Indonesia. Jakarta, Indonesia: Gramedia, 2010. 